\title{
Cell Therapy for Myocardial Infarction
}

\author{
Yoo-Wook Kwon ${ }^{1}$, Han-Mo Yang ${ }^{1,2}$, Hyun-Jai Cho ${ }^{1,2}$ \\ ${ }^{1}$ Innovative Research Institute for Cell Therapy, Seoul National University Hospital, \\ ${ }^{2}$ Cardiovascular Center, Department of Internal Medicine, Seoul National University Hospital, Seoul, Korea
}

Ischemic heart disease, particularly acute myocardial infarction (MI), is the worldwide health care problem and the leading cause of morbidity and mortality. The fundamental treatment of MI remains a major unmet medical need. Although recent tremendous advances have been made in the treatment for acute MI such as percutaneous coronary intervention (PCI) and medical and surgical therapies, myocardial cell loss after ischemia and subsequent, adverse cardiac remodeling and heart failure are demanding for new therapeutic strategy. Since the first experimental studies of adult stem cell therapy into the ischemic heart were performed in the early 1990s, the identification and potential application of stem and/or progenitor cells has triggered attempts to regenerate damaged heart tissue and cell-based therapy is a promising option for treatment of MI. In this review, we would like to discuss the pathogenesis of acute MI, current standard treatments and their limitation, clinical results of recent stem or progenitor cell therapy which have shown a favorable safety profile with modest improvement in cardiac function, and putative mechanisms of benefits.

Keywords: Myocardial infarction, Ischemic heart disease, Stem cells, Cell therapy, Regenerative medicine

\section{Introduction}

Ischemic heart disease, particularly acute myocardial infarction (MI), is the worldwide health care problem and the leading cause of morbidity and mortality (1). Myocardial cell loss after ischemia and subsequent, adverse cardiac remodeling and heart failure are demanding for new therapeutic strategy. Although recent tremendous advances have been made in the treatment for MI such as percutaneous coronary intervention (PCI) and medical and surgical therapies, myocardial cell loss after ischemia and subsequent, adverse cardiac remodeling and heart failure are demanding for new therapeutic strategy $(2,3)$.

\footnotetext{
Accepted for publication April 9, 2010

Correspondence to Hyun-Jai Cho

Division of Cardiology, Department of Internal Medicine, Innovative Research Institute for Cell Therapy (IRICT), Seoul National University Hospital, 101 Daehang-ro (28 Yeongeondong), Jongno-gu, Seoul 110-744, Korea

Tel: +82-2-2072-3931, Fax: +82-2-3675-0805

E-mail: hyunjaicho@snu.ac.kr
}

Regenerative medicine is seeking for an innovative therapeutic strategy that assures to ameliorate health and quality of life by restoring or regenerating cells, tissues or organs. Cellular therapy using stem/progenitor cells has been experimentally and clinically investigated to regenerate or repair the damaged heart (2-4). The adult heart had been believed not to have a capacity of self-regenerating cells $(5,6)$. In this context, over the past decade, various types of extracardiac cells such as bone marrow (BM)-derived cells, adipose-derived stem cells, skeletal myoblasts as well as embryonic stem cell-derived cardiomyocytes have been proposed as potential cell sources for cardiac cell therapy (2-4, 7-12). Experimental preclinical studies have been shown promising results for cardiac repair after acute $\mathrm{MI}$; reduction of infarct size and improvement of left ventricular systolic function (13). However, cardiac differentiation of extracardiac cells remains under heavy debate $(14,15)$, and clinical trials, especially BM-derived cells, have shown modest or marginal benefits when transplanted into acute or chronic MI patients $(16,17)$.

In this review, we would like to discuss the pathophysio- 
logy of acute MI, diagnosis and current conventional treatments and their limitation, clinical results of application of stem and/or progenitor cell therapy for MI, and putative mechanisms of benefits. We also discuss the open issues for future advance.

\section{Pathophysiology of acute MI}

MI is defined as an event caused by myocardial ischemia in which there is evidence of myocardial injury and/or necrosis. Most cases of MI are resulted from coronary atherosclerosis with superimposed coronary thrombosis, although non-atherogenic forms of coronary disease may cause MI $(18,19)$. During the progression of atherosclerotic plaque, especially which is lipid laden, an abrupt transition would occur, characterized by plaque disruption (20). When plaque disruption occurs, thrombogenic substances are exposed, and the lumen of coronary artery becomes obstructed by a combination of platelet aggregates, fibrin, and red blood cells that produce thrombus filling of the infarct-related artery (21). Such occlusive thrombi lead to a zone of necrosis in the ventricular wall.

The pathology of MI is defined as cardiomyocyte cell death as a consequence of prolonged ischemia. Characteristic findings include coagulation necrosis and contraction band necrosis, often with patchy areas of myocytolysis at the periphery of the infarct. During the acute phase of MI, the majority of cardiomyocyte loss in the infarct zone occurs via coagulation necrosis and proceeds to inflammation and phagocytosis of necrotic myocytes, and repair as fibrotic scar formation.

\section{Diagnosis of acute MI}

The clinical diagnosis of MI requires an integrated assessment of the history with combination of (in)direct evidence of myocardial necrosis using biochemical, electrocardiographic, and imaging modalities (22). In 2007, the Joint Task Force of the European Society of Cardiology, American College of Cardiology Foundation, the American Heart Association, and the World Health Federation (ESC/ACCF/AHA/WHF) refined the old criteria and defined acute $\mathrm{MI}$ as a clinical event consequent to the death of cardiomyocytes (myocardial necrosis) that is caused by ischemia (23). The diagnosis of MI is required the followings: Typical rise and/or gradual fall (troponin) or more rapid rise and fall (CK-MB) of biochemical markers of myocardial necrosis with at least one of the following (24, 25): (1) Ischemic symptoms, (2) Development of pathologic Q waves on the electrocardiography (ECG), (3) ECG changes indicative of ischemia (ST segment elevation or depression), (4) Imaging evidence of new loss of viable myocardium or a new regional wall motion abnormality. Myocarditis or trauma can cause cell death and myocardial necrosis but these cases are not defines as MI.

\section{Current treatment of acute $\mathrm{MI}$ and limitations}

The management of the patient MI has been emphasized on prompt diagnosis, because the beneficial effects of early reperfusion therapy are the greatest when performed soon after the onset of symptoms after hospital presentation. A number of hospitals usually apply checklists, or critical pathways to screen patients with a suspected MI, which combine diagnostic evaluation such as ECG and serum biomarkers with therapeutic interventions such as aspirin, beta blockers and antithrombotic therapy. When MI is diagnosed, early reperfusion therapy for occluded coronary arteries is the major therapeutic strategy. Reperfusion can be obtained mechanical or biochemical measures; percutaneous coronary intervention (PCI) or fibrinolytic therapy (24-26). However, there is a very narrow therapeutic window to prevent myocardial necrosis. Usually 3 to 6 hours after MI onset, the efficacy of reperfusion therapy and the extent of salvaged myocardium by reperfusion is abruptly declined, and 12 hours after MI, the therapeutic benefit of reperfusion is marginal, so cardiologists believe that "Time is myocardium" as the longstanding axiom (27).

Pharmacological treatments including antiplatelet agents, beta blockers, ACE inhibitors and angiotensin II receptor blockers and statin are also important $(24,25,28)$. Taken together, recent progress in the management of patients with an acute $\mathrm{MI}$ has led to a decline morbidity and mortality. Nevertheless, survivors of an MI still face a substantial excess risk of mortality as well as further cardiovascular events including angina, recurrent $\mathrm{MI}$ and heart failure.

The critical limit of current standard treatments for MI is that the damaged cardiac muscles and vessels could not be regenerated. The heart has been considered as a static organ and the capacity of the hearts to regenerate functional myocardium is extremely limited or absent. Not surprisingly, it has been thought that the prognosis of $\mathrm{MI}$ is dismal while the long-term survival rate of infarct patients was even worse than that of cancer patients. Therefore, the demand for the regeneration of cardiac muscle and vessel is tremendous. 
Table 1. Clinical trial for acute $\mathrm{Ml}$ using bone marrow-derived cells

\begin{tabular}{|c|c|c|c|c|c|c|}
\hline Study name & $\begin{array}{l}\text { Enrolled } \\
\text { patient No. }\end{array}$ & Cell type & Delivery route & $\begin{array}{l}\text { Myocardial function } \\
\text { (LVEF change \%) }\end{array}$ & $\begin{array}{l}\text { Infarct size } \\
\text { (change \%) }\end{array}$ & Reference \\
\hline MAGIC-Cell I & 27 & $\begin{array}{l}\text { G-CSF mobilized } \\
\text { PB-MNCs }\end{array}$ & Intracoronary & $(+) 6.4 \%$ & $(-) 6.3 \%$ & 29 \\
\hline MAGIC-Cell III-DES & 56 & $\begin{array}{l}\text { G-CSF mobilized } \\
\text { PB-MNCs }\end{array}$ & Intracoronary & $(+) 5.2 \%$ & $\bullet$ & 34 \\
\hline Strauer et al. & 20 & BM-MNCs & Intracoronary & $(+) 1.0 \%$ & (-) $13.0 \%$ & 30 \\
\hline Bartunek et al. & 35 & BM-MNCs & Intracoronary & $(+) 3.1 \%$ & $(-) 4.9 \%$ & 31 \\
\hline BOOST & 60 & BM-MNCs & Intracoronary & $(+) 2.8 \%$ & $\bullet$ & 32,41 \\
\hline Janssens et al. & 67 & BM-MNCs & Intracoronary & $(+) 1.1 \%$ & $\bullet$ & 33 \\
\hline ASTAMI & 100 & BM-MNCs & Intracoronary & $(+) 1.4 \%$ & $(-) 3.2 \%$ & 35,44 \\
\hline REPAIR-AMI & 204 & BM-MNCs & Intracoronary & $(+) 2.5 \%$ & • & $36,42,43$ \\
\hline TCT-STAMI & 20 & BM-MNCs & Intracoronary & $(+) 6.7 \%$ & $(-) 5.0 \%$ & 37 \\
\hline Meluzin et al. & 66 & BM-MNCs & Intracoronary & $(+) 2.0 \%$ & $(-) 1.0 \%$ & 38 \\
\hline Zhan-Quan et al. & 70 & BM-MNCs & Intracoronary & $(+) 5.5 \%$ & $\cdot$ & 39 \\
\hline
\end{tabular}

BM-MNCs: bone marrow-mononuclear cells; PB-MNCs: peripheral blood-mononuclear cells; LVEF: left ventricular ejection fraction.

\section{Application of stem or progenitor cell therapy for $\mathrm{MI}$}

Since 2001, more than 1,000 MI patients have received stem/progenitor cell therapy.

Clinical trials may be classified by applied cell types and delivery routes. A variety of cells have been tested experimentally. At present, majority of trials have primarily used autologous cells, especially, BM cells or mobilized peripheral blood cells, largely due to safe profiles of infused cells and accumulated clinical experience of BM reconstitution or transplantation in patients. Regarding the route of delivery, in the clinical setting of MI, PCI is routinely performed, so intracoronary cell infusion easily and widely applied, compared to other delivery methods such as intramyocardial direct injection. In this review, we focus on trials using BM-derived cells or mobilized peripheral blood cells from BM via intracoronary delivery. Table 1 summarizes the results from 11 clinical trials (29-39).

When clinical trials with stem cells begin, it is very important whether the methods used in the trials are safe and have the feasibility or not. In terms of the intracoronary application of stem cells in patients with acute MI, Strauser et al. first showed the safety and the effect of autologous BM stem cells in 2002 (30). Kang et al. also demonstrated that the mobilization of stem/progenitor cells from BM with G-CSF was safe and had the significant effect in improving left ventricular systolic function (29). In particular, compared to other trials using BM aspiration, they used less invasive strategy such as GCSF-induced mobilization and apheresis to collect mononuclear cells. Interestingly, they reported the high rate of in-stent restenosis in patients who received G-CSF. After that, they showed that the use of drug-eluting stents could overcome that kind of problem with enhancing heart function $(34,40)$. Large randomized controlled trials have shown the beneficial effects of stem/progenitor cell therapy on the infracted myocardium in acute MI patients. In BOOST trial, 60 patients were randomized and received either intracoronary BM-mononuclear cells (BM-MNCs) or standard therapy. BM-MNC-treated group showed the improvement in left ventricular ejection fraction of $2.8 \%$, compared to control group $(32,41)$. REPAIR-AMI study which enrolled 204 patients showed the improvement in left ventricular ejection fraction by $2.5 \%$ in AMI patients $(36,42,43)$. However, the ASTAMI trial showed no definite effect of intracoronary infusion of BM-MNCs on left ventricular function in the patients, compared to that in the control group at 6 months after the treatment $(35,44)$.

In summary, BM-derived cell therapy in acute MI patients may improve left ventricular ejection fraction from $1.0 \%$ up to $6.7 \%$ and reduce infarct size by $1.0 \sim 13.0 \%$. These results suggest the modest improvements in the pathphysiologic parameters.

\section{Mechanisms of benefits}

Currently tremendous experimental or clinical data have repeatedly demonstrated that cell-based therapy for acute MI improve cardiac function and reduce infarct size. However, the underlying mechanisms explaining these benefits remain elusive. We discuss here the possible beneficial mechanisms by which stem/progenitor cells achieve a functional improvement. Diverse types of stem cells 
have been considered as source for cell therapy. Cells are classified as their origin and characterized by specific markers, genetic and proteomic differences. They also differ in their hierarchy to form one or more differentiated cell types. Embryonic stem (ES) cells are the most hierarchical cell types and differentiate into a variety of cell types and tissues, including cardiomyocytes and endothelial cells. Recently, ES cell transplantation has shown a remarkable improvement in cardiac function and structure, and the cells appear to be electrically integrated in animal models of MI and non-ischemic cardiomyopathy (45-47). However, there are ethical problems regarding by using of human embryo as well as immune rejection after transplantation in patients. To develop patient-specific stem cells, Yamanaka group generated induced pluripotent stem cells (iPSCs) with defined factors (Oct4, Sox2, Klf4 and c-Myc) from somatic cells (48-50). According to recent data, human iPSCs can differentiate into functional myocytes and regeneration of cardiac, smooth muscle and endothelial tissue in mouse models (51). Therefore, the iPSCs may provide an alternative source for the future regenerative medicine.

In contrast to ES cells or iPSCs, adult stem cells including BM-derived progenitor cells and resident cardiac stem cells, display more limited differentiation capacity. They were shown to contribute to neovascularization and cardiomyogenesis respectively. To enhance neovasculariza- tion in MI patients, it can be mediated by the physical incorporation of vascular progenitor cells into new capillaries (52) or subsequent delivery of growth factors and cytokines that enhance angiogenesis by affect on mature endothelial cells $(53,54)$. Humoral and paracrine factors including cytokines released from various stem/progenitor cells may favorably affect improvement of cardiac function by reducing the apoptosis of cardiomyocytes or even by activating cardiac stem cells to enhance cardio-myogenesis (55).

Mobilization strategy is also a way to improve cardiac repair. Many well-known angiogenic factors such as VEGF, angiopoietin-1, placental growth factor (PIGF) and SDF-1 were reported to increase mobilization of endothelial progenitor cells (EPCs) and enhance neovascularization (5658). As injected BM-derived cells into infarcted myocardium could differentiate into cardiomyocytes and improve the heart regeneration effectively, hematopoietic stem cellmobilizing factors such as G-CSF and SCF could be applied to MI patients (59). To success cell therapy, mobilized progenitor cells need to home where they are required, specifically to the injured sites. The cascade of homing is adhesion to activated endothelium, transmigration and invasion of the injured tissue. Integrins usually mediated adhesion and transmigration of progenitor cells and SDF-1 appears to be a key molecule to regulate homing of progenitor cells into ischemic tissue $(60,61)$.

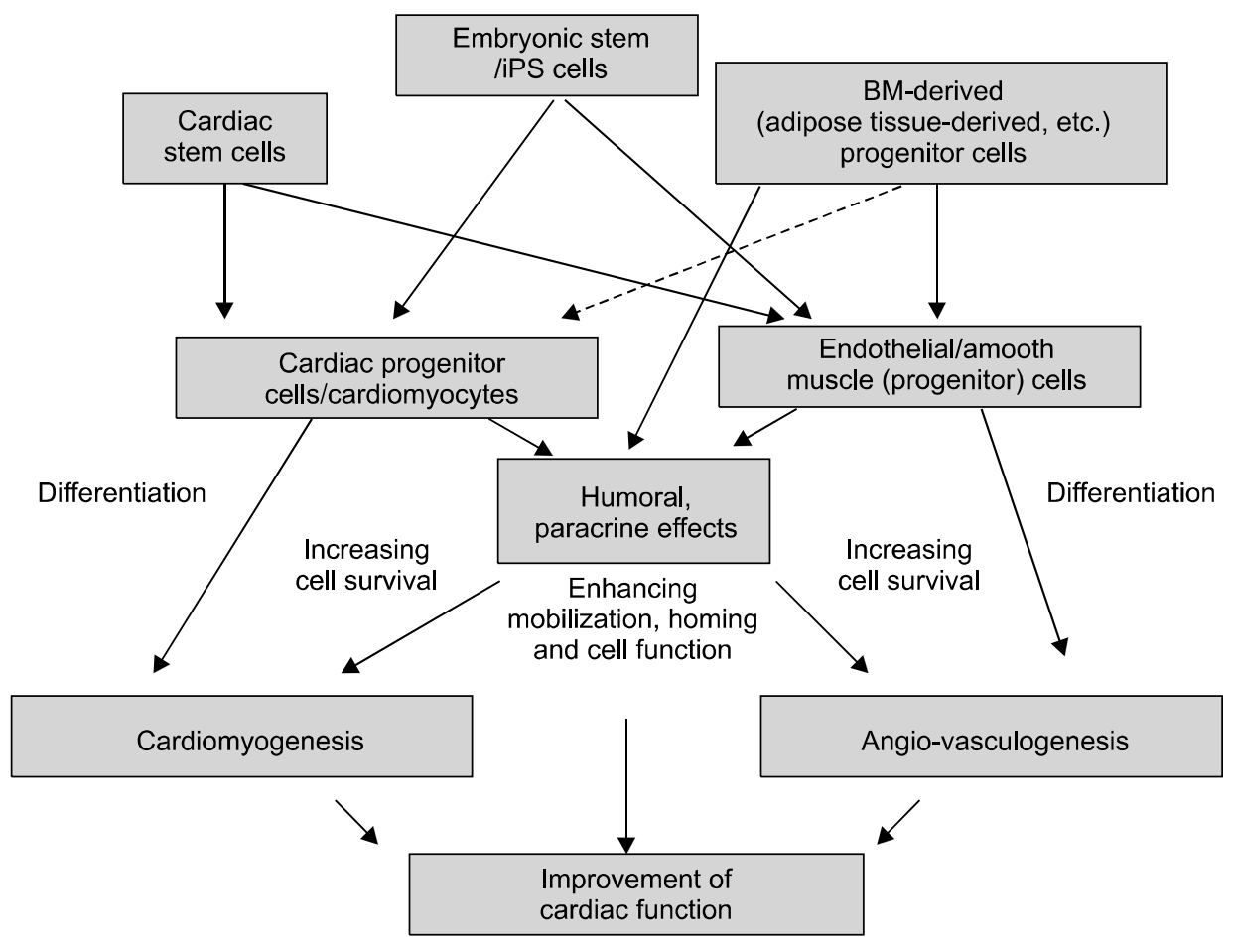

Fig. 1. Putative beneficial mechanisms of cell therapy for Ml. 
Fig. 1 summarizes putative beneficial mechanisms of cell therapy for MI.

\section{Future perspective and open questions}

Stem/progenitor cell research has been making rapid progress and clinical trials, especially using autologous adult stem cells, have been already reported their results and many more are undergoing. However, there are many remaining questions regarding the translational research from experimental animal studies to humans, therapeutic potentials of human adult stem/progenitor cells and clinical benefits: (1) The specific type and role of cells in may be misunderstood or overestimated. Which patients could have benefits from cell therapy has yet to be determined. The clinical setting of ischemic cardiovascular diseases and the components requiring regeneration should be considered. (2) The development of therapeutic strategies to induce both neovascularization and cardiomyogenesis are required since both processes are intimately related in successful and favorable myocardial remodeling and regeneration. (3) We need to acknowledge that not all the stem/progenitor cells possess the same therapeutic capacity and efficacy. Further investigations are needed to compare the therapeutic effects and the underlying mechanisms of different types of stem and progenitor cells, and the advantage of mixed cell therapy may need to be investigated. (4) The cell preparation, transplantation cell dose and volume, the timing of therapy, route of delivery need and clinical study design to evaluate the efficacy of cell therapy need to be determined by more sophisticated approaches. Then, the problem of lack of cellular engraftment and extensive cell death after cell transplantation should be addressed for improving therapeutic efficacy. (5) The long-term benefits the following cell therapy also has to be determined.

Overall, the transplantation of stem and/or progenitor for MI is currently not at the stage in routine clinical practice. Despite these limitations, many clinicians and experimental scientists may agree that cell-based therapy would become a potentially effective strategy for treating MI in near future.

\section{Acknowledgments}

This study was supported by the grant from the Innovative Research Institute for Cell Therapy (A062260), Republic of Korea.

\section{Potential Conflict of Interest}

The authors have no conflicting financial interest.

\section{References}

1. WHO. World Health Report. www.who.int/whr/.

2. Dimmeler S, Burchfield J, Zeiher AM. Cell-based therapy of myocardial infarction. Arterioscler Thromb Vasc Biol 2008;28:208-216

3. Chavakis E, Koyanagi M, Dimmeler S. Enhancing the outcome of cell therapy for cardiac repair: progress from bench to bedside and back. Circulation 2010;121:325-335

4. Bai X, Yan Y, Song YH, Seidensticker M, Rabinovich B, Metzele R, Bankson JA, Vykoukal D, Alt E. Both cultured and freshly isolated adipose tissue-derived stem cells enhance cardiac function after acute myocardial infarction. Eur Heart J 2009;31:489-501

5. MacLellan WR, Schneider MD. Genetic dissection of cardiac growth control pathways. Annu Rev Physiol 2000;62: 289-319

6. Chien KR, Olson EN. Converging pathways and principles in heart development and disease: CV@CSH. Cell 2002; 110:153-162

7. Ferrari G, Angelis GCD, Coletta M, Paolucci E, Stornaiuolo A, Gossu G, Mavilio F. Muscle regeneration by bone marrow-derived myogenic progenitors. Science 1998;279:15281530

8. Gussoni E, Soneoka Y, Strickland CD, Buzney EA, Khan MK, Flint AF, Kunkel LM, Mulligan RC. Dystrophin expression in the mdx mouse restored by stem cell transplantation. Nature 1999;401:390-394

9. LaBarge MA, Blau HM. Biological progression from adult bone marrow to mononucleate muscle stem cell to multinucleate muscle fiber in response to injury. Cell 2002; 111:589-601

10. Fuchs S, Baffour R, Zhou YF, Shou M, Pierre A, Tio FO, Weissman NJ, Leon MB, Epstein SE, Kornowski R. Transendocardial delivery of autologous bone marrow enhances collateral perfusion and regional function in pigs with chronic experimental myocardial ischemia. J Am Coll Cardiol 2001;37:1726-1732

11. Kamihata H, Matsubara H, Nishiue T, Fujiyama S, Tsutsumi Y, Ozono R, Masaki H, Mori Y, Iba O, Tateishi E, Kosaki A, Shintani S, Murohara T, Imaizumi T, Iwasaka T. Implantation of bone marrow mononuclear cells into ischemic myocardium enhances collateral perfusion and regional function via side supply of angioblasts, angiogenic ligands, and cytokines. Circulation 2001;104:1046-1052

12. Shintani S, Murohara T, Ueno T, Ikeda H, Duan J, Imaizumi T. Local transplantation of autologous bone marrow-derived mononuclear cells augments collateral vessel formation in ischemic hindlimb in rabbits. Circulation 2000; 100:I-406

13. Cho HJ, Lee N, Lee JY, Choi YJ, Ii M, Wecker A, Jeong JO, Curry C, Qin G, Yoon YS. Role of host tissues for sustained humoral effects after endothelial progenitor cell transplantation into the ischemic heart. J Exp Med 2007; 204:3257-3269

14. Murry CE, Reinecke H, Pabon LM. Regeneration gaps: ob- 
servations on stem cells and cardiac repair. J Am Coll Cardiol 2006;47:1777-1785

15. Reinecke H, Minami E, Zhu WZ, Laflamme MA. Cardiogenic differentiation and transdifferentiation of progenitor cells. Circ Res 2008;103:1058-1071

16. Lipinski MJ, Biondi-Zoccai GG, Abbate A, Khianey R, Sheiban I, Bartunek J, Vanderheyden M, Kim HS, Kang HJ, Strauer BE, Vetrovec GW. Impact of intracoronary cell therapy on left ventricular function in the setting of acute myocardial infarction: a collaborative systematic review and meta-analysis of controlled clinical trials. J Am Coll Cardiol 2007;50:1761-1767

17. Abdel-Latif A, Bolli R, Tleyjeh IM, Montori VM, Perin EC, Hornung CA, Zuba-Surma EK, Al-Mallah M, Dawn B. Adult bone marrow-derived cells for cardiac repair: a systematic review and meta-analysis. Arch Intern Med 2007; 167:989-997

18. Falk E, Shah PK, Fuster V. Coronary plaque disruption. Circulation 1995;92:657-671

19. Dalager-Pedersen S, Ravn HB, Falk E. Atherosclerosis and acute coronary events. Am J Cardiol 1998;82:37T-40T

20. Kristensen SD, Ravn HB, Falk E. Insights into the pathophysiology of unstable coronary artery disease. Am J Cardiol 1997;80:5E-9E

21. Fuster V, Moreno PR, Fayad ZA, Corti R, Badimon JJ. Atherothrombosis and high-risk plaque: part I: evolving concepts. J Am Coll Cardiol 2005;46:937-954

22. Alpert JS, Thygesen K, Antman E, Bassand JP. Myocardial infarction redefined--a consensus document of the joint European society of cardiology/American college of cardiology committee for the redefinition of myocardial infarction. J Am Coll Cardiol 2000;36:959-969

23. Thygesen K, Alpert JS, White HD; Joint ESC/ACCF/ AHA/WHF Task Force for the Redefinition of Myocardial Infarction. Universal definition of myocardial infarction. J Am Coll Cardiol 2007;50:2173-2195

24. Anderson JL, Adams CD, Antman EM, Bridges CR, Califf RM, Casey DE Jr, Chavey WE 2nd, Fesmire FM, Hochman JS, Levin TN, Lincoff AM, Peterson ED, Theroux P, Wenger NK, Wright RS, Smith SC Jr, Jacobs AK, Halperin JL, Hunt SA, Krumholz HM, Kushner FG, Lytle BW, Nishimura R, Ornato JP, Page RL, Riegel B; American College of Cardiology; American Heart Association Task Force on Practice Guidelines (Writing Committee to Revise the 2002 Guidelines for the Management of Patients With Unstable Angina/Non ST-Elevation Myocardial Infarction); American College of Emergency Physicians; Society for Cardiovascular Angiography and Interventions; Society of Thoracic Surgeons; American Association of Cardiovascular and Pulmonary Rehabilitation; Society for Academic Emergency Medicine. ACC/AHA 2007 guidelines for the management of patients with unstable angina/non ST-elevation myocardial infarction: a report of the American College of Cardiology/American Heart Association Task Force on Practice Guidelines (Writing Committee to Revise the 2002 Guidelines for the Management of Patients With Unstable
Angina/Non ST-Elevation Myocardial Infarction): developed in collaboration with the American College of Emergency Physicians, the Society for Cardiovascular Angiography and Interventions, and the Society of Thoracic Surgeons: endorsed by the American Association of Cardiovascular and Pulmonary Rehabilitation and the Society for Academic Emergency Medicine. Circulation 2007;116:e148304

25. Kushner FG, Hand M, Smith SC Jr, King SB 3rd, Anderson JL, Antman EM, Bailey SR, Bates ER, Blankenship JC, Casey DE Jr, Green LA, Hochman JS, Jacobs AK, Krumholz HM, Morrison DA, Ornato JP, Pearle DL, Peterson ED, Sloan MA, Whitlow PL, Williams DO; American College of Cardiology Foundation/American Heart Association Task Force on Practice Guidelines. 2009 Focused Updates: ACC/ AHA Guidelines for the Management of Patients With STElevation Myocardial Infarction (updating the 2004 Guideline and 2007 Focused Update) and ACC/AHA/SCAI Guidelines on Percutaneous Coronary Intervention (updating the 2005 Guideline and 2007 Focused Update): a report of the American College of Cardiology Foundation/American Heart Association Task Force on Practice Guidelines. Circulation 2009;120:2271-2306

26. Prasad A, Stone GW, Aymong E, Zimetbaum PJ, McLaughlin M, Mehran R, Garcia E, Tcheng JE, Cox DA, Grines CL, Gersh BJ; CADILLAC trial. Impact of ST-segment resolution after primary angioplasty on outcomes after myocardial infarction in elderly patients: an analysis from the CADILLAC trial. Am Heart J 2004;147:669-675

27. Gersh BJ, Stone GW, White HD, Holmes DR Jr. Pharmacological facilitation of primary percutaneous coronary intervention for acute myocardial infarction: is the slope of the curve the shape of the future? JAMA 2005;293:979-986

28. Halkin A, Grines CL, Cox DA, Garcia E, Mehran R, Tcheng JE, Griffin JJ, Guagliumi G, Brodie B, Turco M, Rutherford BD, Aymong E, Lansky AJ, Stone GW. Impact of intravenous beta-blockade before primary angioplasty on survival in patients undergoing mechanical reperfusion therapy for acute myocardial infarction. J Am Coll Cardiol 2004; 43:1780-1787

29. Kang HJ, Kim HS, Zhang SY, Park KW, Cho HJ, Koo BK, Kim YJ, Soo Lee D, Sohn DW, Han KS, Oh BH, Lee MM, Park YB. Effects of intracoronary infusion of peripheral blood stem-cells mobilised with granulocyte-colony stimulating factor on left ventricular systolic function and restenosis after coronary stenting in myocardial infarction: the MAGIC cell randomised clinical trial. Lancet 2004;363: 751-756

30. Strauer BE, Brehm M, Zeus T, Kostering M, Hernandez A, Sorg RV, Kogler G, Wernet P. Repair of infarcted myocardium by autologous intracoronary mononuclear bone marrow cell transplantation in humans. Circulation 2002;106: 1913-1918

31. Bartunek J, Vanderheyden M, Vandekerckhove B, Mansour S, De Bruyne B, De Bondt P, Van Haute I, Lootens N, Heyndrickx G, Wijns W. Intracoronary injection of CD133- 
positive enriched bone marrow progenitor cells promotes cardiac recovery after recent myocardial infarction: feasibility and safety. Circulation 2005;112:I178-183

32. Wollert KC, Meyer GP, Lotz J, Ringes-Lichtenberg S, Lippolt P, Breidenbach C, Fichtner S, Korte T, Hornig B, Messinger D, Arseniev L, Hertenstein B, Ganser A, Drexler $\mathrm{H}$. Intracoronary autologous bone-marrow cell transfer after myocardial infarction: the BOOST randomised controlled clinical trial. Lancet 2004;364:141-148

33. Janssens S, Dubois C, Bogaert J, Theunissen K, Deroose C, Desmet W, Kalantzi M, Herbots L, Sinnaeve P, Dens J, Maertens J, Rademakers F, Dymarkowski S, Gheysens O, Van Cleemput J, Bormans G, Nuyts J, Belmans A, Mortelmans L, Boogaerts M, Van de Werf F. Autologous bone marrow-derived stem-cell transfer in patients with ST-segment elevation myocardial infarction: double-blind, randomised controlled trial. Lancet 2006;367:113-121

34. Kang HJ, Lee HY, Na SH, Chang SA, Park KW, Kim HK, Kim SY, Chang HJ, Lee W, Kang WJ, Koo BK, Kim YJ, Lee DS, Sohn DW, Han KS, Oh BH, Park YB, Kim HS. Differential effect of intracoronary infusion of mobilized peripheral blood stem cells by granulocyte colony-stimulating factor on left ventricular function and remodeling in patients with acute myocardial infarction versus old myocardial infarction: the MAGIC Cell-3-DES randomized, controlled trial. Circulation 2006;114(1 Suppl):I145-151

35. Lunde K, Solheim S, Aakhus S, Arnesen H, Abdelnoor M, Egeland T, Endresen K, Ilebekk A, Mangschau A, Fjeld JG, Smith HJ, Taraldsrud E, Grogaard HK, Bjornerheim R, Brekke M, Muller C, Hopp E, Ragnarsson A, Brinchmann JE, Forfang K. Intracoronary injection of mononuclear bone marrow cells in acute myocardial infarction. N Engl J Med 2006;355:1199-1209

36. Schächinger V, Erbs S, Elsasser A, Haberbosch W, Hambrecht R, Holschermann H, Yu J, Corti R, Mathey DG, Hamm CW, Suselbeck T, Assmus B, Tonn T, Dimmeler S, Zeiher AM; REPAIR-AMI Investigators. Intracoronary bone marrow-derived progenitor cells in acute myocardial infarction. N Engl J Med 2006;355:1210-1221

37. Ge J, Li Y, Qian J, Shi J, Wang Q, Niu Y, Fan B, Liu X, Zhang S, Sun A, Zou Y. Efficacy of emergent transcatheter transplantation of stem cells for treatment of acute myocardial infarction (TCT-STAMI). Heart 2006;92:1764-1767

38. Meluzín J, Mayer J, Groch L, Janousek S, Hornacek I, Hlinomaz O, Kala P, Panovsky R, Prásek J, Kamínek M, Stanícek J, Klabusay M, Korístek Z, Navrátil M, Dusek L, Vinklárková J. Autologous transplantation of mononuclear bone marrow cells in patients with acute myocardial infarction: the effect of the dose of transplanted cells on myocardial function. Am Heart J 2006;152:975.e979-915

39. Li ZQ, Zhang M, Jing YZ, Zhang WW, Liu Y, Cui LJ, Yuan L, Liu XZ, Yu X, Hu TS. The clinical study of autologous peripheral blood stem cell transplantation by intracoronary infusion in patients with acute myocardial infarction (AMI). Int J Cardiol 2007;115:52-56

40. Cho HJ, Kim TY, Park KW, Zhang SY, Kim JH, Kim SH,
Hahn JY, Kang HJ, Park YB, Kim HS. The effect of stem cell mobilization by granulocyte-colony stimulating factor on neointimal hyperplasia and endothelial healing after vascular injury with bare-metal versus paclitaxel-eluting stents. J Am Coll Cardiol 2006;48:366-374

41. Meyer GP, Wollert KC, Lotz J, Steffens J, Lippolt P, Fichtner S, Hecker H, Schaefer A, Arseniev L, Hertenstein B, Ganser A, Drexler H. Intracoronary bone marrow cell transfer after myocardial infarction: eighteen months' follow-up data from the randomized, controlled BOOST (BOne marrOw transfer to enhance ST-elevation infarct regeneration) trial. Circulation 2006;113:1287-1294

42. Schachinger V, Tonn T, Dimmeler S, Zeiher AM. Bonemarrow-derived progenitor cell therapy in need of proof of concept: design of the REPAIR-AMI trial. Nat Clin Pract Cardiovasc Med 2006;3(Suppl 1):S23-28

43. Marenzi G, Bartorelli AL. Improved clinical outcome after intracoronary administration of bone marrow-derived progenitor cells in acute myocardial infarction: final 1-year results of the REPAIR-AMI trial. Eur Heart J 2007;28:21722173

44. Beitnes JO, Hopp E, Lunde K, Solheim S, Arnesen H, Brinchmann JE, Forfang K, Aakhus S. Long-term results after intracoronary injection of autologous mononuclear bone marrow cells in acute myocardial infarction: the ASTAMI randomised, controlled study. Heart 2009;95:1983-1989

45. Hodgson DM, Behfar A, Zingman LV, Kane GC, PerezTerzic C, Alekseev AE, Pucéat M, Terzic A. Stable benefit of embryonic stem cell therapy in myocardial infarction. Am J Physiol Heart Circ Physiol 2004;287:H471-479

46. Ménard C, Hagége AA, Agbulut O, Barro M, Morichetti MC, Brasselet C, Bel A, Messas E, Bissery A, Bruneval P, Desnos M, Pucéat M, Menasché P. Transplantation of cardiac-committed mouse embryonic stem cells to infarcted sheep myocardium: a preclinical study. Lancet 2005;366: 1005-1012

47. Yamada S, Nelson TJ, Crespo-Diaz RJ, Perez-Terzic C, Liu XK, Miki T, Seino S, Behfar A, Terzic A. Embryonic stem cell therapy of heart failure in genetic cardiomyopathy. Stem Cells 2008;26:2644-2653

48. Takahashi K, Yamanaka S. Induction of pluripotent stem cells from mouse embryonic and adult fibroblast cultures by defined factors. Cell 2006;126:663-676

49. Yamanaka S. Strategies and new developments in the generation of patient-specific pluripotent stem cells. Cell Stem Cell 2007;1:39-49

50. Takahashi K, Tanabe K, Ohnuki M, Narita M, Ichisaka T, Tomoda K, Yamanaka S. Induction of pluripotent stem cells from adult human fibroblasts by defined factors. Cell 2007; 131:861-872

51. Nelson TJ, Martinez-Fernandez A, Yamada S, Perez-Terzic C, Ikeda Y, Terzic A. Repair of acute myocardial infarction by human stemness factors induced pluripotent stem cells. Circulation 2009;120:408-416

52. Kawamoto A, Tkebuchava T, Yamaguchi J, Nishimura H, Yoon YS, Milliken C, Uchida S, Masuo O, Iwaguro H, Ma 
H, Hanley A, Silver M, Kearney M, Losordo DW, Isner JM, Asahara T. Intramyocardial transplantation of autologous endothelial progenitor cells for therapeutic neovascularization of myocardial ischemia. Circulation 2003;107:461-468

53. Rehman J, Li J, Orschell CM, March KL. Peripheral blood "endothelial progenitor cells" are derived from monocyte/ macrophages and secrete angiogenic growth factors. Circulation 2003;107:1164-1169

54. Urbich C, Aicher A, Heeschen C, Dernbach E, Hofmann WK, Zeiher AM, Dimmeler S. Soluble factors released by endothelial progenitor cells promote migration of endothelial cells and cardiac resident progenitor cells. J Mol Cell Cardiol 2005;39:733-742

55. Gnecchi M, He H, Liang OD, Melo LG, Morello F, Mu H, Noiseux N, Zhang L, Pratt RE, Ingwall JS, Dzau VJ. Paracrine action accounts for marked protection of ischemic heart by Akt-modified mesenchymal stem cells. Nat Med 2005;11:367-368

56. Hattori K, Heissig B, Tashiro K, Honjo T, Tateno M, Shieh JH, Hackett NR, Quitoriano MS, Crystal RG, Rafii S, Moore MA. Plasma elevation of stromal cell-derived factor-1 induces mobilization of mature and immature hematopoietic progenitor and stem cells. Blood 2001;97:3354-3360

57. Hattori K, Heissig B, Wu Y, Dias S, Tejada R, Ferris B, Hicklin DJ, Zhu Z, Bohlen P, Witte L, Hendrikx J, Hackett
NR, Crystal RG, Moore MA, Werb Z, Lyden D, Rafii S. Placental growth factor reconstitutes hematopoiesis by recruiting VEGFR1(+) stem cells from bone-marrow microenvironment. Nat Med 2002;8:841-849

58. Heeschen C, Aicher A, Lehmann R, Fichtlscherer S, Vasa M, Urbich C, Mildner-Rihm C, Martin H, Zeiher AM, Dimmeler S. Erythropoietin is a potent physiologic stimulus for endothelial progenitor cell mobilization. Blood 2003;102:1340-1346

59. Orlic D, Kajstura J, Chimenti S, Limana F, Jakoniuk I, Quaini F, Nadal-Ginard B, Bodine DM, Leri A, Anversa P. Mobilized bone marrow cells repair the infarcted heart, improving function and survival. Proc Natl Acad Sci U S A 2001;98:10344-10349

60. Ceradini DJ, Kulkarni AR, Callaghan MJ, Tepper OM, Bastidas N, Kleinman ME, Capla JM, Galiano RD, Levine JP, Gurtner GC. Progenitor cell trafficking is regulated by hypoxic gradients through HIF-1 induction of SDF-1. Nat Med 2004;10:858-864

61. De Falco E, Porcelli D, Torella AR, Straino S, Iachininoto MG, Orlandi A, Truffa S, Biglioli P, Napolitano M, Capogrossi MC, Pesce M. SDF-1 involvement in endothelial phenotype and ischemia-induced recruitment of bone marrow progenitor cells. Blood 2004;104:3472-3482 